УДК 351:378

DOI https://doi.org/10.32689/2523-4625-2021-1(60)-7

\title{
Марія ОРЕЛ
}

доктор наук $з$ державного управління, професор кафедри публічного адміністрування, ПрАТ «ВНЗ «Міжрегіональна Академія управління персоналом», вул. Фрометівська, 2, м. Київ, Україна, 03039, orelmailm@ukr.net

ORCID: 0000-0002-9071-5602

\section{Mariia OREL}

Doctor of Public Administration, Professor at the Department of Public Administration, Interregional Academy of Personnel Management, 2 Frometivska str., Kyiv, Ukraine, 03039, orelmailm@ukr.net ORCID: 0000-0002-9071-5602

\section{ПРОБЛЕМИ ПУБЛІЧНОГО УПРАВЛІННЯ У СФЕРІ ОСВІТИ В КОВІДНИЙ ПЕРІОД}

\section{PROBLEMS OF PUBLIC EDUCATION MANAGEMENT IN THE COVID PERIOD}

\begin{abstract}
Мета роботи. У статті здійсненно аналіз та окреслено тенденції змін та реагування на них в умовах COVID-19, акиент на освітній процес. Методологія. Дослідження розпочалося з комплексного аналізу управління, актуальних, нагальних проблем, шьо мало на меті здійснити пошук напрямів розвитку ефективної системи управління та визначити подальші напрями адаптаиії та окреслити тендениії змін та реагування на них в умовах COVID-19, акиентуючи увагу на освітній процес. За основу було взято аналітичний аналіз нормативно-правових актів й наукових праџь з використанням контент-аналізу, структурно-функцііонального, системного, компаративного та абстрактно-логічного методів. Наукова новизна. Виходячи 3 цілі статті, аналізу змін, що стосуються порушення попередніх операційних моделей, такі як дистаниійна робота та впровадження ц̧ифрових технологій, які є на часі й потенційно можуть тривати після пандемії, важливим завданням стало з'ясування та розуміння обставини пандемії COVID-19 та того, як організації та співробітники будуть підтримувати себе в «новій нормі» після COVID-19. Внаслідок изього було визначено, низку переваг та певних недоліків навчання. Безумовною перевагою є те, шо воно дешевще ніж звичайний процес навчання. Проте, до можна виокремити такі перешкоди та особливості з якими стикнулися студенти та викладачі: обмежене використання цифрових платформ лише в певних можливостях доступу (обмеження за часом, вимоги технічної реалізації, тощь); обмежені можливості у використанні цифрових платформ під час навчального прочесу як вчителів, учнів, так і батьків; сигнальні обмеження (якість та швидкість Internet зв'язку) під час проведення навчальної діяльності; студенти, як правило, залишають уроки, тому що немає віч-на-віч викладання та навчання; проблемним є виконання завдань в команді тошо. Висновки. Так, було окреслено особливості онлайн навчання: особливість сприйняття інформацї здобувачами; відсутність «природного» візуального контакту та аналіз онлайн платформ для освітніх цілей; додаткове навантаження на викладачів та здобувачів; "Zоот втома»; відсутність чітко визначених уніфікованих правил викладання в умовах пандемії; необхідність опанування нових дієвих методів та інструментів викладання тошь. Було окреслено основну проблематику навчального процесу: недостатньо якісний Інтернет; пасивність здобувачів; очінювання досягнень здобувача; мотивація здобувачів; активне утримування уваги здобувачів; зворотній зв'язок; мотивачія викладачів; списування; технічні проблеми; пасивність викладачів; інші. Організації та співробітники мають розвиватися впродовж усього періоду пандемії, он-лайн навчання, впроваджувати технологічні інновації, змінювати засоби масової інформації для вивчення освітніх програм, необхідність здійснення ефективної реалізації політики дистанційної роботи та планів ичфрової трансформації, загальне збільшення гнучкості організацій і співробітників у питаннях прийняття нових рімень, щуо робить їх більш відкритими для інновацій.
\end{abstract}

Ключові слова: тенденції змін в умовах COVID-19, особливості онлайн навчання, освітній прочес, «Zоот втома», ичифрові платформи.

The purpose of the research. The article analyzes and outlines the trends of change and response to them in the conditions of COVID-19, the emphasis on the educational process. Methodology. The study began with a comprehensive analysis of management, current, pressing issues, which aimed to find ways to develop an effective management system and identify further areas of adaptation and identify trends in change and response to them in COVID-19, focusing on the educational process. The analytical analysis of normative-legal acts and scientific works with the use of content-analysis, structural-functional, systemic, comparative and abstract-logical methods was taken as a basis. Scientific novelty. Based on the purpose of the article, the analysis of changes related to violations of previous operational models, such as remote operation and implementation of digital technologies that are on time and could potentially continue after the pandemic, an important task was to clarify and understand the circumstances of the COVID-19 how organizations and employees will support themselves in the "new norm" after 
COVID-19. As a result, a number of advantages and disadvantages of training have been identified. The undoubted advantage is that it is cheaper than the usual learning process. However, the following obstacles and features faced by students and teachers can be singled out: limited use of digital platforms only in certain access possibilities (time constraints, technical implementation requirements, etc.); limited opportunities in the use of digital platforms during the educational process of teachers, students and parents; signaling restrictions (quality and speed of Internet connection) during training activities; students tend to drop out of school because there is no face-toface teaching and learning; it is problematic to perform tasks in a team, etc. Conclusions. Thus, the features of online learning were outlined: the peculiarity of the perception of information by applicants; lack of "natural" eye contact and analysis of online platforms for educational purposes; additional burden on teachers and applicants; "Zoom fatigue"; lack of clearly defined unified teaching rules in a pandemic; the need to master new effective teaching methods and tools, etc. The main issues of the educational process were outlined: insufficient quality of the Internet; passivity of applicants; evaluation of the applicant's achievements; motivation of applicants; active retention of applicants; Feedback; motivation of teachers; write-off; technical problems; passivity of teachers; others. Organizations and employees must develop throughout the pandemic period, online learning, technological innovation, change media for educational programs, the need for effective implementation of distance work policies and digital transformation plans, general increase in flexibility of organizations and staff in adopting new solutions, making them more open to innovation.

Key words: rends in COVID-19, features of online training, educational process, "Zoom fatigue", digital platforms.

Постановка проблеми у загальному вигляді та іiі зв'язок 3 важливими науковими чи практичними завданнями. Посилення ескалації проблем в управлінні, спричинених, зокрема, старінням населення, економічним спадом, зміною клімату, деглобалізацією, регіональними конфліктами, суспільно-політичними дестабілізаціями, пандемією COVID-19 тощо, спричиняє необхідність забезпечення ефективного публічного управління, дослідження проблеми забезпечення стійкого та прогресивного розвитку індивіда, суспільства та держави загалом, що дедалі стає нагальною темою не лише наукових досліджень, а й політичної еліти у країнах світової спільноти. 3 кінця 2019 року пандемія COVID-19 привернула увагу до теми переосмислення розуміння ефективності управління та механізмів його забезпечення загалом, як з політичної, так й з суспільної точки зору. Тож з'ясування місії та сенсу існування держави, їх трансформація у контексті осмислення взаємозв'язку функцій держави та проблем забезпечення безпеки життєдіяльності індивіда (громадянина), суспільства й власне державних інститутів продовжує перебувати у колі уваги теоретиків та практиків. Трансформаційні зміни середовища функціонування соціальних систем завжди були й $\epsilon$ серйозним викликом щодо спроможності державних інститутів та інституцій адекватно реагувати на вказані зміни. Цей виклик, як правило, переважно, пов'язаний 3 появою нових суперечностей та невизначеностей у політичній, соціальній, економічній та гуманітарній сферах; ускладненням міжнародних відносин та характеру відносин між інститутами політичної влади та суспільства, формуванням нових, непередбачуваних та складно формалізованих обставин та змін середовища функціонування соціальних систем. Стаття має на меті висвітлити загальні тенденції того, як органи державної влади, організації, бізнес, заклади вищої освіти та співробітники реагують та пристосовуються до пандемії, уроки, які вони засвоїли, і як вони будуть змінюватися та адаптуватися в «новій нормі» після COVID-19.

Аналіз останніх досліджень і публікацій. Ще починаючи 3 античних часів та до сьогодення, вказані чинники та проблема забезпечення стійкого та прогресивного розвитку індивіда, суспільства та держави, завжди перебували у колі уваги як філософів, науковців так і практиків. У даному випадку варто вказати, зокрема, на дослідження С. Аристотеля, 3. Баумана, У. Бека, В.Ж. Бодрійяра, М. Орел, 2019 [1-6].

Пандемія COVID-19 безпрецедентним чином вразила організації та співробітників у кожній сфері буття суспільства та індивіда. Організаціям і працівникам різних секторів стало надзвичайно важко працювати в умовах підвищених обмежень мобільності. Пандемія фактично порушила попередні операційні моделі та внесла зміни, такі як дистанційна робота та впровадження цифрових технологій, які $\epsilon$ широкорозповсюдженими і потенційно можуть тривати й після пандемії.

Зважаючи на ці обставини, важливо було запитати, як організації та співробітники будуть підтримувати себе в «новій нормі» після COVID-19. Незважаючи на те, що проводиться багато досліджень щодо COVID-19, немає всебічного уявлення про зміни, що відбулися та продовжують відбуватися на мезо (організаційному) та мікро (індивідуальному) рівнях. Незважаючи на те, що ці тенденції відрізняються в різних секторах, усередині та між країнами, спостерігається загальне збільшення гнучкості організацій і співробітників у прийнятті нових рішень, що робить 
їх більш відкритими для інновацій, на що звертають увагу дослідники Raghavan, Aarthi, Mehmet Akif Demircioglu, Serik Orazgaliyev, вони наводять важливі рекомендації для організацій, щоб зробити ці переходи більш стійкими в середньостроковій та довгостроковій перспективі [7]. Робота Murugan, Rajavel, Singh присвячена дослідженню нестабільності, невизначеності, складності та неоднозначності, яка шокувала та стурбувала кожен сегмент людської цивілізації [8]. Питанням реагування урядів країн в усьому світі щодо запровадження суворого блокування, заходів відстеження контактів та оцифрування, інтенсивності та тривалості обмежень мобільності організацій та працівників різних секторів висвітлені у роботах $[7 ; 9 ; 10 ; 11]$.

Питання безперервності послуг під час COVID-19 в державному секторі аналізували [12; 13]. Аналіз можливостей сприйняття до змін організацій і співробітників, тривалість, інтенсивність та наслідки пандемії COVID19 розглядали [12-14]. У деяких дослідженнях розглядають стійкий перехід як цикл змін [15; 16]. Ми говоримо, що принципи організаційної стійкості істотно зміняться в ситуаціях до, під час і після COVID-19, оскільки COVID19 був серйозною проблемою для організацій i співробітників. Незважаючи на зростання кількості досліджень на цю тему [17-19], існує потреба у більш повному розумінні змін, яких зазнали організації та співробітники під час пандемії, про, що зокрема, разом з автором статті, зазначають Raghavan...[7].

Формулювання цілей статті. Ціллю статті $\epsilon$ аналіз змін, що стосуються порушення попередніх операційних моделей, такі як дистанційна робота та впровадження цифрових технологій, які $\epsilon$ на часі й потенційно можуть тривати після пандемії. Важливим завданням $є$ з'ясування та розуміння обставини пандемії COVID-19, та того, як організації та співробітники будуть підтримувати себе в «новій нормі» після COVID-19. Незважаючи на те, що проводиться багато досліджень щодо COVID-19, немає всебічного уявлення про зміни на мезо (організаційному) та мікро (індивідуальному) рівнях. Також метою $є$ висвітлення загальних тенденцій того, як організації та співробітники пристосовуються до пандемії, уроки, які вони засвоїли, і як вони будуть змінюватися та адаптуватися в «новій нормі» після COVID-19. Щоб досягти цього необхідно проаналізувати існуючі нормативно-правові документи, статті, що стосуються бізнесу та державного управління у некомерційних та комерційних журналах та інші дослідження. Також важли- вим $є$ виявлення загальної тенденції до впровадження дистанційної роботи та цифрових інструментів як на мезо-, так і на макрорівнях, що забезпечить стійкість організацій та робочих місць у новому форматі. Цікавою $\epsilon$ робота [7], щодо розкриває важливі рекомендації для організацій, щоб зробити ці переходи більш стійкими в середньостроковій та довгостроковій перспективі

Виклад основного матеріалу дослідження 3 повним обгрунтуванням здобутих наукових результатів. Пандемія COVID$19 €$ однією 3 найбільш безпрецедентних криз охорони здоров'я 21-го століття. Хвороба, яка виникла в місті Ухань, виявилася подією, що спричинила до нестабільності, невизначеності, складності та неоднозначності, яка шокувала та стурбувала кожен сегмент людської цивілізації [8]. Станом на липень 2021 року він заразив понад 233 мільйони людей і вбив понад 4,7 мільйона людей [7; 9]. Уряди країн в усьому світі запровадили суворі блокування, заходи відстеження контактів та оцифрування, щоб врятувати життя, забезпечуючи безперервність основних послуг. Інтенсивність та тривалість обмежень мобільності суттєво вплинули на організації та працівників різних секторів $[10 ; 11]$.

Безперервність послуг під час COVID-19 стала проблемою в державному секторі $[12 ; 13]$, приватному секторі та неприбутковому секторі. Зазнали змін охорона здоров'я, освіта, державне управління, комунальні послуги тощо. Щоб подолати виклики, організаціям довелося переналаштувати свої ресурси, системи та робочу силу (співробітників). Співробітники зіткнулися з несподіваними змінами у своєму робочому середовищі, і багатьом довелося пристосуватися до структур віддаленої роботи та прийняти цифрові рішення для забезпечення безперервності обслуговування, тоді як інші в таких секторах, як виробництво, були змушені продовжувати роботи на робочому місці. Багато співробітників зіткнулися зі скороченням оплати праці, а деякі навіть втратили роботу під час кризи. Однак позитивним $є$ те, що пандемія дозволила організаціям розвинути стійкість, оскільки вони реагували, відновлювалися та намагалися відтворити себе після пандеміі. Тривалість, інтенсивність та наслідки пандемії COVID-19 дають значну можливість для організацій і співробітників сприйняти зміни [12-14].

Організації та співробітники розвивалися у своїх реакціях на кризу впродовж усього життєвого циклу пандемії. Виходячи з цієї ідеї, було введено структуру Надзвичайна ситуація (нестаціонарна ситуація) - Навчання - Інсти- 
туалізація - Нова реальність, яка допомагає пояснити цей перехід (НHIH). На відміну від деяких досліджень, які розглядають стійкий перехід як цикл змін [15; 16], структура ННIH описує пандемію як порушення, яке піднімає реакцію організацій і співробітників на новий рівень, тобто пост-COVID-19.

Ми говоримо, що принципи організаційної стійкості істотно зміняться в ситуаціях до, під час і після COVID-19, оскільки COVID-19 був серйозною проблемою для організацій і співробітників. Незважаючи на зростання кількості досліджень на цю тему [17-19], існує потреба у більш повному розумінні змін, яких зазнали організації та співробітники під час пандемії, про, що зокрема, разом 3 автором статті, зазначають Raghavan, Aarthi... [7]. Варто також акцентувати увагу на тому, що в умовах сьогодення виникає й необхідність у он-лайн навчанні. Та чи завжди воно $є$ ефективним? Наприклад, у 2021 році $32 \%$ українських випускників «провалили» ЗНО 3 математики (Освітній скандал в україні: чому третина школярів провалила зно 3 математики). Чому це критично? За даними Forbes, 8 з 10 найбільш високооплачуваних професій в Україні потребують значних знань 3 математики(Форбс рейтинг). Якщо ми говоримо про майбутніх фахівців-управлінців, також $є$ над чим замислитися.

Електронне навчання або веб-навчання це певна система дистанційного навчання, яка використовується в процесі навчання через мережу Інтернет або Інтранет 3 використанням системи управління освітою [20]. Впровадження технологічних інновацій змінюють засоби масової інформації для вивчення освітніх програм, щоб допомогти учням та здобувачам у реальному часі чи офлайн опанувати очікувані програмні результати навчання. Електронне навчання має як низку переваг так і певні недоліки. Безумовною перевагою $\epsilon$ те, що воно дешевше ніж звичайний процес навчання [20; 21]. Загалом, логічним є поділ електронного навчання на два підходи:

- асинхронне електронне навчання, як правило, сприяє засобам масової інформації (за допомогою електронної пошти, використання спільних платформ/дошок обговорень для учнів та викладачів, для учнів, які не мають можливості бути в онлайні). Це змушує учнів витрачати більше часу на те, щоб у будьякий час увійти в середовище електронного навчання та завантажити документи чи надіслати повідомлення викладачам чи одноліткам;

- синхронне електронне навчання, яке зазвичай підтримується технічними засобами інформації, такими як відео конферен- ції, чат, спільне використання інтерактивних дошок, Google Disk та ін.. в онлайн, має потенціал для підтримки учнів у розвитку навчальних спільнот. Студенти та викладачі відчувають синхронне електронне навчання щодо того, щоб ставити запитання та відповідати на них у режимі реального часу. Синхронні заняття допомагають учням та здобувачам відчувати себе безпосередньо активно залученими до навчального процесу. Електронне навчання може створити систему навчання для студентів, особливо для отримання матеріалу 3 Інтернету, навіть 3 того місця, де студенти знаходяться, без необхідності зустрічатися віч-на-віч 3 вчителями, якщо вони не в класі. Електронне навчання - це веб-навчання, як системи електронного навчання, які іноді також називають системами управління навчанням (Learning Management Systems (LMS) LMS), які використовуються для розробки, управління та поширення навчальних онлайн-матеріалів із забезпеченням спільного доступу, або віртуальними навчальними середовищами (Virtual Learning Environments (VLE) [20].

3 початком впровадження онлайннавчання, можна виокремити такі перешкоди та особливості з якими стикнулися студенти та викладачі: обмежене використання цифрових платформ лише в певних можливостях доступу (обмеження за часом, вимоги технічної реалізації, тощо); обмежені можливості у використанні цифрових платформ під час навчального процесу як вчителів, учнів, так і батьків; сигнальні обмеження (якість та швидкість Internet звязку) під час проведення навчальної діяльності; студенти, як правило, залишають уроки, тому що немає вічна-віч викладання та навчання; проблемним $€$ виконання завдань в команді.

Проте є багато досліджень, що аналізують бар'єри електронного навчання [22] та онлайн-навчання в звичайних умовах [23]. Варто окреслити особливості онлайн платформи для освітніх цілей: немає потребує реєстрації користувача; немає необхідності завантажувати клієнт програми; працює 3 різних OS/браузерів; просте підключення за посилання; наявність чату для обміну повідомленнями й файлами; функція трансляції екрану; наявність інтерактивної дошки; можливість запису конференції. У якості додаткових переваг можна визначити: можливість переходу між «кімнатами»; можливість підключити кілька спікерів одночасно. Лідерами програмного забезпечення для електронного навчання наразі є Google Meet; Zoom; Moodle; Google Classroom. 
Тож, дослідники зацікавлені в розробці функцій веб-орієнтованого навчання за допомогою Moodle, або модульне об'єктноорієнтоване динамічне середовище навчання (Modular Object-Oriented Dynamic Learning Environment). Архітектура адаптивного електронного навчання - Moodle (Модульне об'єктно-орієнтоване динамічне середовище навчання). Moodle - це система керування курсами (CMS - Course Management System) - програмний пакет, розроблений, щоб допомогти викладачам створювати якісні онлайн-курси, платформу електронного навчання 3 відкритим вихідним кодом, яка представляє чудову платформу для розміщення ресурсів та комунікаційних засобів. Зазвичай, функціями CMS $\epsilon$ завантаження файлів, дискусійні форуми, функції подання завдань, записи календаря, параметри оцінювання, а також модулі зворотного зв'язку, вікторини, тести тощо. CMS $\epsilon$ єдиною спільною організованою системою в режимі онлайн/офлайн на основі курсу та пов'язаною $з$ попередньою реєстрацією всіх учасників на курс. Функції Moodle розроблені дослідниками, таким чином, щоб полегшити роботу не лише вчителям/викладачам та учням, а й батькам. Він має за мету допомогти всім учасникам контролювати викладання та вивчення. Можливостями та перевагами якого є: створення курсів; об'єднання студентів і курсів у класи; щоденник студента; журнал викладача; варіанти графічного інтерфейсу; безкоштовний ресурс; багато варіантів для перевірки; мобільний за стосунок.

Системами дистанційного навчання також є Office 365 - хмарний Інтернет-сервіс і програмне забезпечення від компаніiі Microsoft (можливостями та перевагами зокрема, є: програми для створення курсів; програми для створення тестів; чат із можливістю аудіо і відео комунікації; багато можливостей для автоматизації процесів, безкоштовний ресурс, знайомий інтерфейс тощо); NetAcad - система дистанційного навчання від компанії Cisco (можливостями та перевагами зокрема, $€$ : готові курси 3 напрямків IT, економіки, менеджменту; можливість відкриття академії у закладах вищої освіти; створення власних кусрів і практичних завдань; безкоштовний курс; можливість брати участь в змаганнях та олімпіадах; Google Classroom - веб-сервіс створений Google для навчальних закладів 3 метою спрощення створення, поширення i класифікації завдань без паперовим шляхом (можливостями та перевагами зокрема, є: створення курсів; за стосунок для телефону; щоденник студента; журнал викладача; безкоштовний ресурс; багато варіантів робіт для перевірки; чат із можливістю аудіо і відео комунікації. Schoology - віртуальне навчальне середовище для шкіл та вищих навчальних закладів, що дозволяє користувачам створювати, керувати та ділитися навчальним вмістом (можливостями та перевагами зокрема, $\epsilon$ : створення курсів; інтеграція курсів; щоденник студента; журнал вчителч; безкоштовний ресурс; багато варіантів робіт для перевірки.

Дослідження потребує проблематика щодо: аналізу потреб вчителів Moodle у викладанні та вивченні дисциплін під час COVID-19 пандемії; розробки та удосконалення існуючих структурних функцій Moodle, як електронного навчання для вивчення дисциплін в умовах пандемії COVID-19.

Як правило, більшість дослідників використовували Moodle для вивчення різних дисциплін, зокрема: природничих наук, мови, комп'ютера, математики тощо, щодо управління навчальними програмами та включення процесу рефлексії, щоб допомогти менеджерам вивчити своє минуле та сьогодення, щоб створити нові стратегії для покращення майбутніх управлінських знань/навичок. Використання платформи Moodle у навчанні може допомогти студентам підвищити рівень самостійності навчання, формування навичок сомомотивації та організації. Moodle - це безкоштовна навчальна платформа, яка має деякі функції, які можна використовувати під час навчання. Moodle - це засіб навчання, який може сприяти покращенню знань студентів у результаті активної та спільної діяльності під час навчального процесу. Навчання за допомогою Moodle має значний вплив на підвищення мотивації студентів та навчальних результатів учнів. Навчаючись за допомогою Moodle, викладачi можуть створити середовище для електронного навчання, віртуальне навчальне середовище та конструктивістське навчальне середовище.

Також варто викладачам для активного залучення здобувачів використовувати інструменти: Padlet (Padlet.com) - для інтерактивних вправ; Miro (Miro.com) - для візуалізації та репрезантивних активних завдань; Mindmeister (https://www.mindmeister.com) - для побудови мап мислення, проявам креативності; Mentimeter (https://www.mentimeter. com) - інструмент для реалізації опитування; Google Docs (https://www.google.com/docs/ about/) - спільне використання Docs документів; Jamboard (https://www.jamboard. google.com) - спільна інтерактивна дошка; Opinionstage (https://www.Opinionstage.com) інструмент для створення опитування; Awwapp.com; Kahoot.com; Flippity (flippity.net) - 
для створення онлайн-ігор з метою навчання тощо. Ці та інші ресурси допоможуть здійснювати інтерактивні презентації (чат або/та спілкування вголос); фасилітацію (робота разом на електронній дошці); роботі в групах; індивідуальні завдання; опитування; тестування; ситуативні вправи тощо.

Обираючи рефлексію як інструмент, як потужний ресурс, який допомагає управлінцям трансформувати своє бачення й розуміти, як вони отримують можливість адаптуватися відповідно до своїх сильних та слабких сторін. Іншими словами, процеси рефлексії можуть допомогти управлінцям, вчителям й учням вчитися, досліджуючи їхній минулий i теперішній досвід, щоб приймати рішення щодо свого майбутнього.

Також можна сказати, що в умовах COVID-19 у навчальному процесі окреслилась певна особливість сприйняття інформації здобувачами, так, зокрема, завдяки розвитку інформаційних технологій «відволікатися» здобувачам освіти стало значно легше, ніж це було, принаймні 20 років тому. А зважаючи на те, що покоління, що наразі навчається вже народилося 3 гаджетами, які вже $\epsilon$ частиною їхнього життя, також виникає необхідність врахування цього фактору у процесі навчання. Необхідно зважати на те, що здобувачу достатньо всього 8 секунд аби визначити наскільки та чи інша інформація заслуговує на його увагу. Активна увага переважно може втримуватися 6-8 хвилин. Отже варто орієнтуватися на те, що втримання активної уваги 6-8 хвилин, вимагає певних особливостей викладання, й постійного моніторингу наскільки цікавим буде для здобувачів та чи інша інформація у певний проміжок часу. Тому викладачам в умовах он-лайн навчання необхідно враховувати 3 одного боку психоемоційні особливості здобувачів, а 3 іншого максимально ефективно донести знання та допомогти сформувати практичні навички у здобувачів. Зважаючи на це викладачу потрібно «включити аудиторію» та постійно намагатися підтримувати увагу здобувачів, зокрема, шляхом організації опитування, роботи у кімнатах, групах, організовувати панельні дискусії, візуалізувати подану інформацію шляхом використання он-лайн дошок, спільних презентацій, проведення різних вікторин, створювати умови для мотивації здобувачів до саморозвитку та самоорганізації, забезпечити зворотній зв'язок, організувати та здійснити оцінювання.

Другою особливістю у процесі он-лайн навчання $\epsilon$ відсутність «природного» візуального контакту, тільки очі здобувача та викла- дача, й навіть коли, здобувачі не вимикають камери, спілкування все одно відбувається лише у форматі «очі-в-очі», що впродовж тривалого часу також викликає додаткове навантаження. Тож роль викладача в сучасних умовах он-лайн навчання дещо зміщується від лише лектора до ментора, наставника, а також необхідності не лише вчити, а й постійно вчитися самому.

Вартує звернути увагу й на додаткове навантаження на викладачів, що виникає у зв'язку 3 необхідністю переформатування своїх навчально-методичних комплексів, формату подання інформації та методів контролю, необхідності постійного утримування уваги здобувачів тощо. Тому з'являється таке поняття сучасності як «Zoom втома», яке притаманне не лише викладачам, а й здобувачам. Зважаючи на те, навчання в умовах Covid-19 створило нові виклики та загрози, 3 якими раніше людство не стикалось, природно також говорити про відсутність чітко визначених уніфікованих правил викладання в умовах пандемії, опанування нових дієвих методів та інструментів викладання. Говорячи про он-лайн навчання можна, зокрема, окреслити основну його проблематику: недостатньо якісний Інтернет; пасивність здобувачів; оцінювання досягнень здобувача; мотивація здобувачів; активне утримування уваги здобувачів; зворотній зв'язок; мотивація викладачів; списування; технічні проблеми; пасивність викладачів; інші.

Висновки із цього дослідження i подалыші перспективи в цьому напрямку. Щоб подолати виклики, причинені COVID-19, організаціям довелося переналаштувати свої ресурси, системи та робочу силу (співробітників). Співробітникам довелося пристосуватися до структур віддаленої роботи та прийняти цифрові рішення для забезпечення безперервності обслуговування, тоді як інші в таких секторах, як виробництво, були змушені продовжувати роботи на робочому місці, інколи скорочення оплати праці, а деякі навіть втратили роботу. Однак позитивним $\epsilon$ те, що пандемія дозволила організаціям розвинути стійкість, оскільки вони реагували, відновлювалися та намагалися відтворити себе після пандемії. Тривалість, інтенсивність та наслідки пандемії COVID-19 дають значну можливість для організацій і співробітників сприйняти зміни, зокрема у сфері освіти.

Визначена низка переваг та певних недоліків навчання. Безумовною перевагою $\epsilon$ те, що воно дешевше ніж звичайний процес навчання. Проте, до можна виокремити такі перешкоди та особливості 3 якими стикну- 
лися студенти та викладачі: обмежене використання цифрових платформ лише в певних можливостях доступу (обмеження за часом, вимоги технічної реалізації, тощо); обмежені можливості у використанні цифрових платформ під час навчального процесу як вчителів, учнів, так і батьків; сигнальні обмеження (якість та швидкість Internet зв'язку) під час проведення навчальної діяльності; студенти, як правило, залишають уроки, тому що немає віч-на-віч викладання та навчання; проблемним $є$ виконання завдань в команді тощо.

У статті було окреслено особливості онлайн навчання: особливість сприйняття інформації здобувачами; відсутність «природного» візуального контакту та аналіз онлайн платформ для освітніх цілей; додаткове навантаження на викладачів та здобувачів; «Zoom втома»; відсутність чітко визначених уніфікованих правил викладання в умовах пандемії; необхідність опанування нових дієвих методів та інструментів викладання тощо. Було окреслено основну проблематику навчального процесу: недостатньо якісний Інтернет; пасивність здобувачів; оцінювання досягнень здобувача; мотивація здобувачів; активне утримування уваги здобувачів; зворотній зв'язок; мотивація викладачів; списування; технічні проблеми; пасивність викладачів; інші. Організації та співробітники мають розвиватися впродовж усього періоду пандемії, он-лайн навчання, впроваджувати технологічні інновації, змінювати засоби масової інформації для вивчення освітніх програм, необхідність здійснення ефективної реалізації політики дистанційної роботи та планів цифрової трансформації, загальне збільшення гнучкості організацій і співробітників у питаннях прийняття нових рішень, що робить їх більш відкритими для інновацій.

\section{Література:}

1. Аристотель. Політика / пер. 3 давньогр. та передм. О. Кислюка. К.: Основи. 2000. 239 с.

2. Бауман 3. Текучая современность / пер. с англ. под ред. Ю.В. Асочакова. СПб.: Питер, 2008. 240 с.

3. Бек У. Общество риска. На пути к другому модерну / пер. с нем. В. Седельникова и Н.Федоровой; Послесл. А.Филиппова. М.: Прогресс Традиции, 2000. 384 с.

4. Бодрийяр Ж. Символический обмен и смерть. М. : Добросвет, 2000. 387 с.

5. Бодрийяр Ж. Общество потребления. М. : Республика, Культурная революция, 2006.

6. Орел М.Г. Теоретичні основи державного управління у сфері політичної безпеки: монографія. Київ : «Поліграф плюс», 2019. 320 с.

7. Raghavan Aarthi, Mehmet Akif Demircioglu, and Serik Orazgaliyev. 2021 Covid 19 and the New Normal of Organizations and Employees: An Overview', Sustainability, 13: 11942. URL: https://www.mdpi.com/2071 $1050 / 13 / 21 / 11942$

8. Murugan, S., Rajavel, S., Aggarwal, A.K., Singh, A. Volatility, uncertainty, complexity and ambiguity (VUCA) in context of the COVID 19 pandemic: Challenges and way forward. Int. J. Health Syst. Implement. Res. 2020. № 4. P. 10-16.

9. Worldometer. URL: https://www.worldometers.info/coronavirus/

10. Kniffin K.M., Narayanan J., Anseel F., Antonakis J., Ashford S.P., Bakker A.B., Bamberger P., Bapuji H., Bhave D.P., Choi V.K. et al. COVID 19 and the workplace: Implications, issues, and insights for future research and action. Am. Psychol. 2021. № 76. P. 63.

11. Teleworking during the COVID 19 Pandemic and Beyond: A Practical Guide. URL: https://www.ilo. org/wcmsp5/groups/public/ed_protect/protrav/travail/documents/instructionalmaterial/wcms_751232.pdf

12. Schuster C., Weitzman, L., Sass Mikkelsen, K., Meyer Sahling, J., Bersch, K., Fukuyamā, F., Paskov, P., Rogger, D., Mistree, D., Kay, K. Responding to COVID 19 Through Surveys of Public Servants. Public Adm. Rev. 2020. № 80. P. 792-796.

13. Ansell C., Sørensen E., Torfing J. The COVID 19 pandemic as a game changer for public administration and leadership? The need for robust governance responses to turbulent problems. Public Manag. Rev. 2020. № 23. P. 1-12.

14. Ahmad A., Alshurideh M.T., Al Kurdi B.H., Salloum S.A. Factors Impacts Organization Digital Transformation and Organization Decision Making During Covid19. Ansell, C., Sørensen, E., Torfing, J. The COVID 19 pandemic as a game changer for public administration and leadership? The need for robust governance responses to turbulent problems. Public Manag. Rev. 2020. № 23. P. 1-12.

15. Dar M.A., Gladysz B., Buczacki A. Impact of COVID19 on Operational Activities of Manufacturing Organizations A Case Study and Industry 4.0 Based Survive Stabilise Sustainability (3S) Framework. Energies. 2021. № 14. P. 1900.

16. There Is No Returning to Normal After COVID 19. But There Is a Path Forward. URL: https://www. weforum.org/agenda/2020/04/covid19three horizonsframework/

17. Rai S.S., Rai S., Singh N.K. Organizational resilience and social economic sustainability: COVID 19 perspective. Environ. Dev. Sustain. 2021. P. 1-18. 
18. John J., Thakur R. Long term effects of service adaptations made under pandemic conditions: The new «post COVID 19» normal. Eur. J. Mark. 2021. № 55. P. 1679-1700.

19. Teng Calleja M., Caringal Go J.F.; Manaois J.O., Isidro M., Queenie Y., Zantua R.M.S. Examining organizational response and employee coping behaviors amid the COVID 19 pandemic. J. Behav. Sci. 2020. № 15 . P. 34-50.

20. Lisnani L., Putri R.I.I., Zulkardi and Somakim. Designing Moodle features as e learning for learning mathematics in COVID 19 pandemic. URL: https://iopscience.iop.org/article/10.1088/1742 $6596 / 1657 / 1 / 012024$

21. NCTM 2008 The role of technology in the teaching and learning of mathematics. URL: http://www.nctm.org/about/content.aspx?id=14233

22. Noawanit S. F., Jintavee K., Bundit P., Maneerat L. E learning system to enhance cognitive skills for learners in higher education. Procedia Social and Behavioral Sciences. 2015. № 174. P. 667-673.

23. Arkorful V., Abaidoo N. The role of e learning, the advantages and disadvantages of its adoption in higher education. International Journal of Education and Research 2014. № 2(12). P. 397-410

\section{References:}

1. Aristotel'. (2000), Politika [Politics]. Osnovy, Kyiv, Ukraine

2. Bauman, Z. (2008), Tekuchaja sovremennost' [Flowing modernity], Peter, St. Petersburg, Russia.

3. Bek, U. (2000), Obshhestvo riska. Na puti $k$ drugomu modern [Risk Society. On the way to another modernity], Progress, Moscow, Russia.

4. Bodrijjar, Zh. (2000), Simvolicheskij obmen i smert' [Symbolic exchange and death], Dobrosvet, Moscow, Russia.

5. Bodrijjar, Zh. (2006), Obshhestvo potreblenija [Consumer society], Respublika, Kul'turnaja revoljucija, Moscow, Russia.

6. Orel, M.G. (2019), Teoretychni osnovy derzhavnoho upravlinnia u sferi politychnoi bezpeky [Theoretical Foundations of Public Administration in Political Security], Polihraf plius, Kyiv, Ukraine.

7. Raghavan, Aarthi, Mehmet Akif Demircioglu, and Serik Orazgaliyev. 2021 Covid 19 and the New Normal of Organizations and Employees: An Overview', Sustainability, 13: 11942. Available online: https://www. mdpi.com/2071 1050/13/21/11942

8. Murugan, S.; Rajavel, S.; Aggarwal, A.K.; Singh, A. Volatility, uncertainty, complexity and ambiguity (VUCA) in context of the COVID 19 pandemic: Challenges and way forward. Int. J. Health Syst. Implement. Res. 2020, 4, 10 16. [Google Scholar]

9. Worldometer. Available online: https://www.worldometers.info/coronavirus/

10. Kniffin, K.M., Narayanan, J., Anseel, F., Antonakis, J., Ashford, S.P., Bakker, A.B., Bamberger, P., Bapuji, H., Bhave, D.P., Choi, V.K., et al. (2021), COVID 19 and the workplace: Implications, issues, and insights for future research and action. Am. Psychol, 76, 63.

11. Teleworking during the COVID 19 Pandemic and Beyond: A Practical Guide. Available online: https://www.ilo.org/wcmsp5/groups/public/ ed_protect/ protrav/ travail/documents/instructionalmaterial/ wcms 751232.pdf

12. Schuster, C., Weitzman, L., Sass Mikkelsen, K., Meyer Sahling, J., Bersch, K., Fukuyama, F., Paskov, P., Rogger, D., Mistree, D., Kay, K. (2020), Responding to COVID 19 Through Surveys of Public Servants. Public Adm. Rev, 80, 792-796.

13. Ansell, C., Sørensen, E., Torfing, J. (2020), The COVID 19 pandemic as a game changer for public administration and leadership? The need for robust governance responses to turbulent problems. Public Manag. Rev, 23, 1-12.

14. Ahmad, A., Alshurideh, M.T., Al Kurdi, B.H., Salloum, S.A. (2020), Factors Impacts Organization Digital Transformation and Organization Decision Making During Covid19 Ansell, C., Sørensen, E., Torfing, J. The COVID 19 pandemic as a game changer for public administration and leadership? The need for robust governance responses to turbulent problems. Public Manag. Rev, 23, 1-12.

15. Dar, M.A.; Gladysz, B.; Buczacki, A. (2021), Impact of COVID19 on Operational Activities of Manufacturing Organizations A Case Study and Industry 4.0 Based Survive Stabilise Sustainability (3S) Framework. Energies, 14, 1900.

16. There Is No Returning to Normal After COVID 19. But There Is a Path Forward. Available online: https://www.weforum.org/agenda/2020/04/covid 19 three horizons framework/

17. Rai, S.S., Rai, S., Singh, N.K. (2021), Organizational resilience and social economic sustainability: COVID 19 perspective. Environ. Dev. Sustain, 1-18. [Google Scholar]

18. John, J., Thakur, R. (2021), Long term effects of service adaptations made under pandemic conditions: The new «post COVID 19» normal. Eur. J. Mark, 55, 1679-1700.

19. Teng Calleja, M., Caringal Go, J.F., Manaois, J.O., Isidro, M., Queenie, Y., Zantua, R.M.S. (2020), Examining organizational response and employee coping behaviors amid the COVID 19 pandemic. J. Behav. Sci, 15, 34-50. 
20. Lisnani L., Putri R.I.I., Zulkardi and Somakim. Designing Moodle features as e learning for learning mathematics in COVID 19 pandemic. Available online: https://iopscience.iop.org/article/10.1088/ $17426596 / 1657 / 1 / 012024$

21. NCTM 2008 The role of technology in the teaching and learning of mathematics. Available online: http://www.nctm.org/about/content.aspx?id=14233

22. Noawanit, S. F., Jintavee, K., Bundit, P. and Maneerat, L. (2015), E learning system to enhance cognitive skills for learners in higher education. Procedia Social and Behavioral Sciences, 174, 667-673.

23. Arkorful, V. and Abaidoo, N. (2014), The role of e learning, the advantages and disadvantages of its adoption in higher education. International Journal of Education and Research, 2 (12), 397-410. 